\title{
Dukungan keluarga dan jadwal makan sebelum edukasi berhubungan dengan kepatuhan jadwal makan pasien diabetes melitus (DM) tipe 2 rawat jalan yang mendapat konseling gizi di RSUD Kota Yogyakarta ${ }^{1}$
}

\author{
Martalena Br Purba², Endah Sri Rahayu ${ }^{3}$, Hemi Sinorita ${ }^{4}$
}

\begin{abstract}
Background:

Diabetes mellitus (DM) is a clinical syndrome with symptoms of hyperglycemia, urinary glucose excretion and disorder of insulin mechanism. Approximately $90-95 \%$ of diabeteic patients suffer from type 2 DM. Various studies show that compliance to treatment of chronic disease in general is low. Compliance to eating or food frequency amongst DM patients in hospital in particular is very low. The success of self management of blood glucose (SMBG) needs participation of the patient, families, and educator team.

Objective: To study the factors affecting eating compliance particularly eating schedule among type 2 diabetic out-patient who had nutrition counseling in RSUD Kota Yogyakarta.

Method: It was an observasional study with cross sectional design and purposive sampling. Data collection was done in October 2008 with 98 subjects. The sampel were type 2 diabetic out-patients according to inclusion criteria at outpatient clinic in RSUD Kota Yogyakarta. Statistical test with 95\% confidence interval was applied to investigate factors influenced eating compliance.

Results: There were no correlations between eating compliance and disease duration $(R P=1,253$ and $p=0,403)$, and also with type of occupation $(R P=1,047$ dan $p=1,000)$. However, it was found that family support affected eating compliance $(R P=1,723$ dan $p=0,025)$ as well as eating schedule before nutrition counseling $(R P=2,151$ and $p=0,02)$.

Conclusion: Duration of disease and type of occupation did not affect eating compliance. Nevertheless, family support and eating schedule before nutrition education affected eating compliance among type 2 DM out-patients in RSUD Kota Yogyakarta.
\end{abstract}

KEY WORDS compliance, eating schedule, type 2 diabetes mellitus

\section{PENDAHULUAN}

Kemajuan di bidang teknologi, industri, perbaikan ekonomi pada lapisan masyarakat tertentu, perubahan perilaku dan lingkungan, serta meningkatnya umur harapan hidup menyebabkan pergeseran pola penyakit dari penyakit menular menjadi penyakit degeneratif (1). Menurut data statistik International Diabetes Federation (IDF) tahun 1995, Indonesia menempati urutan ke-7 dengan jumlah penderita Diabetes Mellitus (DM) terbesar di dunia setelah India, Cina, Amerika, Rusia, Jepang, dan Brazil sebanyak 4,5 juta penduduk sehingga diprediksi pada tahun 2025 jumlah penderita DM akan meningkat menjadi 12,4 juta penduduk (2).

DM merupakan suatu sindroma klinik yang ditandai oleh adanya kenaikan kadar glukosa darah di atas normal, ekskresi glukosa melalui air seni dan gangguan mekanisme kerja hormon insulin (3). Data statistik mengenai DM tipe 1 belum ada, diperkirakan hanya sekitar 2-3\% sedangkan $90-95 \%$ penderita DM adalah penderita DM tipe 2 (2). Data Departemen Kesehatan (Depkes), jumlah penderita DM rawat inap maupun rawat jalan di rumah sakit menempati urutan pertama dari seluruh penyakit endokrin. Penyakit DM di Rumah Sakit Umum Daerah (RSUD) Kota Yogyakarta menduduki peringkat ke-1 dari penyakit terbanyak untuk rawat jalan tahun 2007 dengan jumlah kunjungan pasien sebanyak 8.138 orang (Rekam medis RSUD Kota Yogyakarta, 2007). ${ }^{1}$

Penyakit DM tidak dapat disembuhkan, namun kadar glukosa darahnya dapat dikendalikan untuk memperlambat terjadinya komplikasi pada organ tubuh antara lain: pembuluh darah otak, pembuluh darah mata, pembuluh darah jantung, pembuluh darah ginjal, dan pembuluh darah kaki (1). Oleh karena itu, kontrol glukosa darah merupakan suatu indikator penting untuk membantu pengobatan dan pencegahan komplikasi (2). Penatalaksanaan DM pada umumnya dibedakan menjadi terapi primer dan sekunder. Terapi primer meliputi edukasi, diet, dan olahraga

\footnotetext{
1 Dipresentasikan pada International Dietetic Update pada tanggal 1517 Oktober 2009 di Yogyakarta kerjasama dengan Asosiasi Dietisien Indonesia, Jurnal Gizi Klinik Indonesia, dan Prodi Gizi Kesehatan FKUGM serta didanai oleh Pendidikan Tinggi Kementerian Pendidikan Nasional

2 Instalasi Gizi RSUP Dr. Sardjito, Jl.Kesehatan, Yogyakarta, e-mail: martalena_purba@yahoo.com

3 Jurusan Gizi Poltekkes Jayapura, Papua, email: en772000@yahoo. com

${ }^{4}$ Sub-bagian Endokrin, Bagian Penyakit Dalam Fakultas Kedokteran, Universitas Gadjah Mada
} 
sedangkan terapi sekunder meliputi obat hipoglikemik oral, insulin dan cangkok pankreas (4).

Berbagai penelitian menunjukkan bahwa kepatuhan pada pengobatan penyakit yang bersifat kronik, pada umumnya rendah. Penelitian pada pasien DM, didapatkan $80 \%$ di antaranya menyuntik insulin dengan cara tidak tepat, $58 \%$ memakai dosis yang salah, dan $75 \%$ tidak mengikuti diet yang dianjurkan (5). Tingkat kepatuhan frekuensi jadwal makan pasien DM rawat jalan di RSUD Sleman masih sangat rendah yaitu 42 subjek (7\%) (6).

Ketidakpatuhan merupakan salah satu hambatan untuk tercapainya tujuan pengobatan DM. Untuk mengatasi ketidakpatuhan edukasi bagi penyandang DM, partisipasi pasien dan keluarganya mutlak diperlukan karena penyakit DM merupakan penyakit yang berhubungan dengan gaya hidup terutama pola makan penyandang DM. Penyandang DM yang mempunyai pengetahuan cukup tentang DM, kemudian mengubah perilakunya akan dapat mengendalikan kondisi penyakit sehingga hidup menjadi lebih berkualitas (7). Keberhasilan pengelolaan DM mandiri membutuhkan partisipasi aktif pasien, keluarga dan masyarakat dan dukungan tim edukator yang terdiri dari dokter, ahli gizi, perawat, dan tenaga kesehatan lain (8).

Pasien DM yang memiliki pengetahuan, sikap, dan keterampilan yang memadai tentang standar diet yang tepat serta mengaplikasikannya dalam diet sehari-hari diharapkan berat badan dan kadar glukosa darahnya dapat dikendalikan sehingga mencegah komplikasi lebih lanjut (9). Dalam pelaksanaan diet pada pasien DM ada 3 kesalahan yang menjadi masalah antara lain kurangnya pengetahuan yang diderita, lupa dalam melaksanakan diet tepat waktu, dan kurangnya komitmen dalam pelaksanaan $\operatorname{diet}(10)$.

Penelitian di RSU Gunung Jati Cirebon menunjukkan bahwa asupan energi, karbohidrat, dan lemak berhubungan dengan pengendalian kadar glukosa darah pada pengidap DM tipe 2, sedangkan asupan protein tidak berhubungan dengan pengendalian kadar glukosa darah. Jadwal makan pada pengidap DM tipe 2 tidak berhubungan dengan pengendalian kadar glukosa darah. Hal tersebut disebabkan karena jadwal makan yang baik pada pengidap DM dalam penelitian ini tidak diikuti dengan jumlah porsi makanan yang dianjurkan (11).

Sedangkan penelitian di RSUD Noongan Sulawesi Utara menunjukkan bahwa konseling gizi dengan buku saku diet dan aplikasinya dalam kehidupan sehari-hari memegang peranan penting dalam penatalaksanaan penyakit hiperurisemia. Pasien hiperurisemia yang diberi konseling gizi dengan buku saku diet, disertai petunjuk dan penjelasan rinci cara menerapkannya dalam menu setiap hari, serta diberikannya pengertian dan pemahaman tentang manfaat diet terhadap pemeliharaan kesehatan akan terdorong untuk menerapkan peraturan diet yang diberikan dalam mengonsumsi makanan sehari-hari (12).
Berdasarkan latar belakang di atas maka dapat dibuat rumusan masalah penelitian yaitu apakah lama menderita DM, aktivitas pekerjaan, jadwal makan sebelum mendapatkan edukasi, serta dukungan keluarga berhubungan dengan kepatuhan jadwal makan pasien DM yang pernah mendapatkan edukasi perencanaan makan. Penelitian ini bertujuan untuk mengetahui faktor-faktor yang mempengaruhi kepatuhan jadwal makan pasien DM tipe 2 rawat jalan dan pernah mendapatkan edukasi di RSUD Kota Yogyakarta.

\section{BAHAN DAN METODE}

Penelitian ini merupakan penelitian observasional dengan rancangan penelitian cross sectional, yaitu wawancara dan pengisian kuesioner untuk mengetahui faktor-faktor yang mempengaruhi kepatuhan jadwal makan pasien DM tipe 2 rawat jalan yang pernah mendapatkan edukasi perencanaan makan.

Lokasi penelitian dilakukan di Poliklinik Penyakit Dalam RSUD Kota Yogyakarta, pemilihan tempat penelitian ini dengan pertimbangan bahwa Rumah Sakit Kota Yogyakarta merupakan salah satu Rumah Sakit di Yogyakarta dengan jumlah pasien DM yang banyak sehingga mudah mendapatkan kasus. Menurut pengetahuan peneliti, belum pernah dilakukan penelitian serupa di lokasi tersebut.

Populasi pada penelitian ini adalah semua pasien DM yang datang ke Poliklinik Penyakit Dalam RSUD Kota Yogyakarta. Subjek penelitian adalah semua populasi pasien DM tipe 2 yang memenuhi kriteria inklusi selama periode bulan Oktober 2008, yang meliputi bersedia menjadi subjek, berumur 25-65 tahun, pernah mendapatkan edukasi perencanaan makan dari ahli gizi, dan berdomisili di Yogyakarta. Adapun kriteria eksklusi yaitu dalam keadaan hamil atau menyusui, menderita komplikasi penyakit hati dan ginjal, dan menderita penyakit neurodegeneratif yang menyulitkan komunikasi. Teknik pengambilan sampling menggunakan metode purposive sampling. Sebanyak 98 orang atau subjek yang memenuhi kriteria inklusi dan eksklusi selama periode pengambilan data.

Variabel penelitian meliputi: 1). Variabel independen: dukungan keluarga, aktivitas pekerjaan, lama menderita DM, jadwal makan sebelum edukasi; 2).Variabel dependen: kepatuhan jadwal makan. Dukungan keluarga diperoleh dengan cara melakukan wawancara dengan orang terdekat subjek misalnya suami/istri atau anak dengan menanyakan tindakan mereka dalam hal memberikan perhatian dan motivasi dalam hal mengingatkan jadwal makan, jenis makanan, serta jumlah makanan yang boleh dikonsumsi. Pengumpulan data dukungan keluarga menggunakan kuesioner yang berjumlah 14 pertanyaan dan menggunakan skala Likert. 
Cara pengumpulan data dilakukan melalui 2 tahap, yaitu saat subjek berkunjung ke Poliklinik Penyakit Dalam Kota Yogyakarta dilakukan wawancara menggunakan metode recall $1 \times 24$ jam dan pasien diberikan kartu food record $2 \times 24$ jam yang diisi oleh pasien. Pengumpulan data dilakukan oleh peneliti dibantu enumerator dengan melakukan home visit maupun wawancara melalui telepon. Data primer meliputi data umum: nama, jenis kelamin, umur, alamat, tingkat pendidikan, riwayat keluarga yang menderita DM, lama menderita DM, aktivitas pekerjaan, dan jadwal makan sebelum edukasi dikumpulkan dengan menggunakan kuesioner. Sementara data dukungan keluarga dalam bentuk sikap dan tindakan anggota keluarga, diperoleh melalui wawancara langsung dengan keluarga pasien saat mengantar pasien untuk kontrol. Apabila pasien datang sendiri maka data diperoleh melalui home visit. Pengumpulan data dilakukan oleh peneliti dibantu enumerator sebanyak 3 orang dengan kualifikasi lulusan D3 Gizi.

Setelah data dikumpulkan selanjutnya diedit dan diberi kode untuk memudahkan proses entry data mengunakan komputer. Analisis data dilakukan secara kuantitatif untuk menguji kebenaran hipotesis. Penelitian ini menggunakan dua macam analisis yaitu analisis univariat dan analisis bivariat. Analisis univariat untuk melihat gambaran distribusi frekuensi dari masing-masing variabel yang disajikan, penyajian hasil analisis untuk mengetahui karakteristik subjek dengan menganalisis variabel-variabel yang ada secara deskriptif dan menghitung frekuensi serta proporsinya. Analisis bivariat melihat hubungan antara dua variabel yaitu variabel bebas dan terikat dengan uji chi square dan Fisher's exact dengan tingkat kepercayaan yang digunakan sebesar $95 \%$.

Nilai rasio prevalensi (RP) digunakan untuk mengetahui besarnya prevalensi variabel bebas terhadap variabel terikat sedangkan nilai 95\% Confidence Interval $(\mathrm{Cl})$ menunjukkan taksiran rentang nilai pada populasi yang dihitung dengan nilai yang diperoleh pada subjek penelitian.

\section{HASIL DAN BAHASAN}

\section{Karateristik subjek}

Selama periode pengambilan data, diperoleh sebanyak 98 orang subjek yang memenuhi kriteria inklusi. Karakteristik subjek dapat dilihat pada Tabel 1.

Berdasarkan hasil wawancara, maka diperoleh bahwa rata-rata waktu subjek menderita DM adalah kurang lebih 71 bulan (5,9 tahun). Subjek dengan lama menderita DM tertinggi yaitu 360 bulan (30 tahun) dan terendah adalah 3 bulan. Lama menderita DM dikategorikan menjadi 2 yaitu kurang dari 71 bulan dan lebih atau sama dengan 71 bulan. Pada Tabel 1 terlihat sebanyak 61 orang dari 98 subjek $(62,2 \%)$ mempunyai rata-rata lama menderita DM kurang dari 71 bulan sedangkan sisanya 37 orang $(37,8 \%)$ subjek
Tabel 1. Karakteristik subjek di Poliklinik Penyakit Dalam RSUD Kota Yogyakarta

\begin{tabular}{|c|c|c|}
\hline Variabel & $\mathbf{n}$ & $\%$ \\
\hline \multicolumn{3}{|l|}{ Umur } \\
\hline 25-45 tahun & 4 & 4,1 \\
\hline $46-65$ tahun & 94 & 95,9 \\
\hline \multicolumn{3}{|l|}{ Jenis kelamin } \\
\hline Pria & 28 & 28,6 \\
\hline Wanita & 70 & 71,4 \\
\hline \multicolumn{3}{|l|}{ Pendidikan } \\
\hline SD & 11 & 11,2 \\
\hline SMP & 19 & 19,4 \\
\hline SMA & 34 & 34,7 \\
\hline PT & 34 & 34,7 \\
\hline \multicolumn{3}{|l|}{ Riwayat keluarga DM } \\
\hline Ya & 48 & 49 \\
\hline Tidak & 50 & 51 \\
\hline \multicolumn{3}{|l|}{ Lama menderita DM } \\
\hline$<71$ bulan & 61 & 62,2 \\
\hline$\geq 71$ bulan & 37 & 37,8 \\
\hline \multicolumn{3}{|l|}{ Aktivitas pekerjaan } \\
\hline Ringan & 39 & 39,8 \\
\hline Sedang plus berat & 59 & 60,2 \\
\hline \multicolumn{3}{|c|}{ Jadwal makan sebelum edukasi } \\
\hline Sama & 19 & 19,4 \\
\hline Tidak sama & 79 & 80,6 \\
\hline \multicolumn{3}{|l|}{ Dukungan keluarga } \\
\hline Baik & 47 & 48 \\
\hline Kurang baik & 51 & 52 \\
\hline \multicolumn{3}{|l|}{ Kepatuhan jadwal makan } \\
\hline Patuh & 44 & 44,9 \\
\hline Tidak patuh & 54 & 55,1 \\
\hline
\end{tabular}

lama menderita DM lebih dari sama dengan 71 bulan.

Aktivitas pekerjaan subjek terbagi atas dua kategori yaitu ringan dan sedang plus berat, ditemukan bahwa pada aktivitas pekerjaan berat jumlah subjek tidak memenuhi syarat dilakukan uji statistik, sehingga dilakukan pemindahan dengan cara menggabungkan data agar memenuhi syarat pengujian chi-square (13). Kemudian didapatkan dua pengategorian jenis pekerjaan berdasarkan aktivitas yaitu ringan dan sedang plus berat. Berdasarkan Tabel 1 terlihat bahwa aktivitas pekerjaan terbanyak adalah sedang plus berat sebanyak 59 orang $(60 \%)$ subjek dan aktivitas pekerjaan ringan sebanyak 39 orang $(40 \%)$ subjek.

Jadwal makan subjek sebagian besar tidak sama dengan anjuran ahli gizi yaitu sebanyak 79 orang dari 98 subjek (81\%), sedangkan yang mempunyai jadwal makan sama dengan anjuran ahli gizi berjumlah 19 orang dari 98 subjek (19\%), dapat dilihat pada Tabel 1.

Hasil wawancara dengan keluarga subjek diketahui bahwa sebagian besar subjek kurang mendapatkan dukungan dari keluarganya dalam hal memperhatikan jadwal makan subjek. Tabel 1 memperlihatkan jumlah subjek yang kurang mendapat dukungan adalah 51 orang $(52 \%)$ subjek sedangkan yang dukungan keluarga tergolong dalam kategori baik sebanyak 47 orang (48\%) subjek. 


\section{Analisis bivariat}

Untuk mengetahui adanya hubungan antara variabel bebas yaitu lama menderita DM, aktivitas pekerjaan, dukungan keluarga, dan jadwal makan sebelum edukasi dengan variabel terikat yaitu kepatuhan jadwal makan dilakukan uji bivariat, hasil analisis disajikan pada Tabel 2.

\section{Hubungan lama menderita DM, aktivitas pekerjaan, dan dukungan keluarga dengan kepatuhan jadwal makan sebelum edukasi}

Berdasarkan Tabel 2, diketahui bahwa sebanyak 36 orang dari 98 subjek $(36,7 \%)$ dengan lama menderita DM kurang dari 71 bulan, kepatuhan jadwal makannya termasuk dalam kategori tidak patuh. Subjek dengan lama menderita DM berkisar lebih atau sama dengan 71 bulan sebanyak 18 orang dari 98 subjek (18,4\%), tergolong tidak patuh pada jadwal makan.

Hasil uji statistik chi square diperoleh nilai RP (rasio prevalensi) sebesar 1,253 dan nilai $p$ sebesar $0,403(95 \% \mathrm{Cl}=$ 0,811-1,935), maka dapat disimpulkan tidak ada perbedaan proporsi kejadian ketidakpatuhan jadwal makan pada subjek dan nilai $p$ sebesar $1,000(95 \% \mathrm{Cl}=0,677-1,633)$, maka dapat disimpulkan tidak ada hubungan yang signifikan antara aktivitas pekerjaan dengan kepatuhan jadwal makan subjek.

Berdasarkan hasil analisis diperoleh hasil bahwa ada sebanyak 34 dari 98 (34,7\%) subjek dengan dukungan keluarga kurang baik yang tidak patuh pada jadwal makan. Subjek dengan dukungan keluarga baik ada 20 dari 98 subjek $(20,4 \%)$ yang tidak patuh pada jadwal makan. Hasil uji statistik Fisher's exact diperoleh nilai rasio prevalensi sebesar kemaknaan statistik p sebesar 0,014 (95\% Cl=1,088-2,729) yang berarti ada hubungan dukungan keluarga dengan kepatuhan jadwal makan subjek (Tabel 2).

Dari Tabel 2 di atas terlihat bahwa subjek yang mempunyai jadwal makan sebelum mendapatkan edukasi sama dengan anjuran sebanyak 4 orang dari 98 subjek $(4,1 \%)$ tidak patuh pada jadwal makan, sedangkan subjek yang mempunyai jadwal makan tidak sama dengan anjuran ahli gizi sebanyak 50 orang dari 98 subjek $(51,0 \%)$ tidak patuh pada jadwal makan.

Hasil uji statistik diperoleh nilai signifikansi statistik sebesar 0,002 yang berarti ada hubungan jadwal makan

Tabel 2. Hubungan lama menderita DM, aktivitas fisik, dukungan keluarga, serta jadwal makan dengan kepatuhan jadwal makan subjek di Poliklinik Penyakit Dalam RSUD Kota Yogyakarta

\begin{tabular}{|c|c|c|c|c|c|c|c|c|}
\hline \multirow{3}{*}{ Variabel } & \multicolumn{4}{|c|}{ Kepatuhan jadwal makan } & \multirow{2}{*}{\multicolumn{2}{|c|}{ Total }} & \multirow{3}{*}{ RP } & \multirow{3}{*}{$95 \% \mathrm{Cl}$} \\
\hline & \multicolumn{2}{|c|}{ Patuh } & \multicolumn{2}{|c|}{ Tidak patuh } & & & & \\
\hline & $\mathbf{n}$ & $\%$ & $\mathbf{n}$ & $\%$ & $\mathbf{n}$ & $\%$ & & \\
\hline \multicolumn{9}{|l|}{ Lama menderita $\mathrm{DM}^{\mathrm{a}}$} \\
\hline$<71$ bulan & 25 & 25,5 & 36 & 36,7 & 61 & 62,2 & 1,253 & $0,811-1,935$ \\
\hline$\geq 71$ bulan & 19 & 19,4 & 18 & 18,4 & 37 & 37,8 & & \\
\hline \multicolumn{9}{|l|}{ Aktivitas $^{a}$} \\
\hline Ringan & 18 & 18,4 & 21 & 21,4 & 39 & 39,8 & 1,047 & $0,677-1,633$ \\
\hline Sedang+Berat & 26 & 26,5 & 33 & 33,7 & 59 & 60,2 & & \\
\hline \multicolumn{9}{|c|}{ Jadwal makan sebelum edukasi ${ }^{b}$} \\
\hline Sama & 15 & 15,3 & 4 & 4,1 & 19 & 19,4 & 2,151 & $1,481-3,117^{*}$ \\
\hline Berbeda & 29 & 29,6 & 50 & 51,0 & 79 & 80,6 & & \\
\hline \multicolumn{9}{|l|}{ Dukungan keluarga ${ }^{a}$} \\
\hline Baik & 27 & 27,6 & 20 & 20,4 & 47 & 48 & 1,723 & $1,088-2,729^{* *}$ \\
\hline Kurang & 17 & 17,3 & 34 & 34,7 & 51 & 52 & & \\
\hline
\end{tabular}

Keterangan:

auji chi square

${ }^{b}$ uji Fisher's exact

* = signifikan ( $p<0,05$; uji Fisher's exact)

** = signifikan $(p<0,05$; uji chi square)

yang telah menderita DM kurang dari 71 bulan dengan subjek yang telah menderita DM lebih atau sama dengan 71 bulan. Subjek dengan lama menderita DM lebih atau sama dengan 71 bulan mempunyai kecenderungan 1,253 kali tidak patuh pada jadwal dibandingkan dengan subjek yang lama menderita DM-nya kurang dari 71 bulan.

Tabel 2 menunjukkan bahwa terdapat sebanyak 21 dari $98(21,4 \%)$ subjek dengan aktivitas pekerjaan ringan yang tidak patuh pada jadwal makan. Sedangkan aktivitas pekerjaan sedang plus berat yang tidak patuh pada jadwal makan terdapat pada 33 orang dari 98 subjek $(33,7 \%)$ Hasil uji statistik chi square diperoleh nilai RP sebesar 1,047 subjek sebelum edukasi dengan kepatuhan jadwal makan. Hasil analisis tabulasi silang menunjukkan bahwa nilai hasil perhitungan RP sebesar 2,151 (95\% Cl =1,481-3,117).

\section{BAHASAN}

\section{Hubungan lama menderita DM dengan kepatuhan jadwal makan}

Pada penelitian ini sebagian besar subjek yaitu sebanyak 61 orang $(62,2 \%)$ mengidap DM selama kurang dari 71 bulan (5,9 tahun). Namun hubungan lama menderita 
DM dengan kepatuhan jadwal makan tidak bermakna secara statistik (Tabel 2). DM merupakan salah satu penyakit degeneratif yang bersifat kronik (4) di mana lama menderita DM dapat mempengaruhi tingkat depresi pasien (14). Hal ini tidak sesuai dengan beberapa penelitian yang menyatakan bahwa tingkat kepatuhan pada pengobatan penyakit kronik pada umumnya rendah (5). Beberapa diabetisi mengalami kebosanan dan putus asa untuk menjalankan diet, sehingga tidak jarang diabetisi mencari kesembuhan dan penyelesaian masalahnya melalui pengobatan alternatif (15). DM seringkali menyebabkan pasien menjadi frustasi, marah secara berlebihan, dan berkecil hati terhadap penyakit yang diderita (16).

Hasil penelitian tidak signifikan dapat disebabkan karena kepatuhan merupakan tahap pertama dari perubahan perilaku, di mana pada tahap ini seseorang akan patuh apabila masih ada pengawas atau petugas kesehatan yang mengawasinya (17). Hal ini dapat mempengaruhi seseorang yang patuh terhadap jadwal makan sesuai anjuran ahli gizi, tidak tergantung berapa lama seseorang menderita DM. Walaupun secara statistik hubungan kedua variabel tidak signifikan, namun nilai rasio prevalensi sebesar 1,253 (95\% $\mathrm{Cl}=1,935)$ menunjukkan bahwa lama menderita DM lebih atau sama dengan 71 bulan merupakan faktor risiko untuk tidak patuh terhadap jadwal makan.

\section{Hubungan aktivitas pekerjaan dengan kepatuhan jadwal makan}

Kerja merupakan sesuatu yang dibutuhkan oleh manusia (18), aktivitas pekerjaan digolongkan menjadi aktivitas ringan, sedang, berat, dan sangat berat (19). Pengategorian aktivitas pekerjaan subjek terdiri atas dua yaitu ringan dan sedang plus berat. Aktivitas pekerjaan berdasarkan aktivitas sedang plus berat menunjukkan persentase yang lebih tinggi dibandingkan aktivitas pekerjaan ringan. Berdasarkan hasil uji statistik diperoleh nilai $p$ sebesar 1,000 yang menyatakan bahwa aktivitas pekerjaan diabetisi tidak berhubungan dengan kepatuhan jadwal makan. Hal ini bertentangan dengan penelitian di RSUD Sleman yang menyatakan bahwa sebagian besar diabetisi tidak patuh dalam menjalankan jadwal diet karena diabetisi merasa kesulitan dengan tuntutan kerja yang terkadang membuat lupa (6).

Pada penelitian ini, hasil yang tidak signifikan dapat disebabkan karena sebagian besar subjek merupakan pensiunan pegawai negeri dan ibu rumah tangga. Hal itu membuat jadwal makan tidak konsisten setiap hari. Kemudian, aktivitas pekerjaan dilakukan tanpa batasan tertentu dan berdasarkan kemampuan masing-masing subjek, sehingga jadwal makan sangat beragam antara satu subjek dengan subjek lainnya. Berbeda jika subjek yang diperoleh bekerja di kantor atau mempunyai aktivitas pekerjaan yang dibatasi oleh waktu, sehingga kepatuhan terhadap jadwal makan dapat tergambarkan.

\section{Hubungan dukungan keluarga dengan kepatuhan jadwal makan}

Hasil penelitian menunjukkan bahwa sebagian besar subjek yaitu sebanyak 51 orang (52\%) memiliki dukungan yang kurang baik dari keluarganya. Dukungan keluarga yang kurang baik ternyata berhubungan pada kepatuhan subjek untuk mengikuti jadwal makan yang dianjurkan oleh ahli gizi dengan nilai RP sebesar $1,723(p=0,014$; $95 \% \mathrm{Cl}=1,088-2,729)$. Hal ini terkait dengan pernyataan bahwa DM merupakan penyakit kronis yang menyebabkan diabetisi merasa bosan dan stres sehingga tindakan terhadap faktor psikologis sangat membantu penyelesaian masalah DM (15).

Dukungan keluarga adalah sikap, tindakan, dan penerimaan keluarga terhadap penderita yang sakit. Keluarga memiliki empat fungsi dukungan yaitu: dukungan informasional, dukungan penilaian, dukungan instrumental, dan dukungan emosional (20). Kepatuhan merupakan tahap pertama dari perubahan perilaku sehingga seorang pasien membutuhkan pengawasan dalam hal mengubah perilakunya, di mana salah satu anggota keluarga dapat dijadikan sebagai pengawas dalam hal mengikuti anjuran ataupun terapi yang diberikan oleh tenaga medis.

Salah satu fungsi dukungan keluarga adalah dukungan emosional yaitu keluarga merupakan tempat yang aman dan damai untuk istirahat dan pemulihan serta membantu penguasaan terhadap emosi, ada perasaan terlindungi (6). Keluarga dapat mempunyai pengaruh positif kepada sikap penyandang DM untuk menerima edukasi tentang pengaturan makan yang dianjurkan oleh ahli gizi, sehingga berhasilnya pengobatan DM bergantung pada kerja sama petugas kesehatan, penyandang DM dan keluarganya (5). Sehingga untuk meningkatkan kepatuhan pasien DM terhadap jadwal makan yang telah dianjurkan oleh ahli gizi, peran keluarga sangat penting untuk dilibatkan.

\section{Hubungan jadwal makan sebelum edukasi dengan kepatuhan jadwal makan}

Sebagian besar subjek yaitu sebanyak 79 orang $(80,6 \%)$ mempunyai jadwal makan sebelum edukasi tidak sama dengan anjuran ahli gizi. Berdasarkan hasil penelitian diperoleh bahwa ada hubungan jadwal makan subjek sebelum edukasi dengan kepatuhan jadwal makan yang sesuai dengan anjuran ahli gizi $(p=0,02$; $95 \% \mathrm{Cl}=1,481-3,117)$. Hal ini dapat disebabkan karena subjek yang mempunyai jadwal makan tidak sama akan mengalami kesulitan untuk menyesuaikan diri dan mengubah perilakunya untuk patuh pada jadwal makan yang telah dianjurkan oleh ahli gizi.

Ahli antropologi Mead menyatakan bahwa pola pangan berhubungan dengan kebiasaan seseorang dan dipengaruhi oleh aspek sosial budaya, lingkungan, agama, pendidikan, dan masyarakat (21). Hal tersebut 
memungkinkan karakteristik jadwal makan antara tiap individu berbeda. Pengaturan jadwal makan merupakan suatu tahap perilaku yang baru bagi pasien DM, apabila perilaku tersebut dianggap positif bagi pasien maka akan diintegrasikan dengan nilai-nilai dalam hidupnya (17). Perubahan tersebut melalui beberapa tahapan yang memerlukan adaptasi dalam diri pasien yang tidak mempunyai jadwal makan yang sama dengan yang dianjurkan ahli gizi yaitu, 3 kali makan utama dan 3 kali makan selingan, sehingga dalam memberikan edukasi dapat ditemui banyak kegagalan karena pasien tersebut sangat sulit untuk menerapkan jadwal makan yang baru setelah menerima edukasi. Oleh sebab itu, tenaga medis perlu melakukan pendekatan pada pasien dan perubahan perilaku perlu dilakukan secara bertahap disesuaikan dengan kebiasaan diabetisi (9) dan edukasi yang diberikan terus menerus seumur hidup bagi pasien DM .

\section{KESIMPULAN DAN SARAN}

Pada penelitian ini diperoleh kesimpulan bahwa kepatuhan jadwal makan pasien DM tidak berhubungan dengan berapa lama pasien tersebut menderita DM, tidak berhubungan juga dengan aktivitas pekerjaan yang dilakukan. Namun, berhubungan dengan dukungan yang diberikan oleh keluarga dan karakteristik jadwal makan yang sama dengan anjuran ahli gizi sebelum diberikan edukasi oleh ahli gizi.

Keluarga penderita DM dianjurkan untuk mendukung setiap penderita dalam mengikuti pola makan seperti yang dianjurkan ahli gizi. Adapun bentuk dukungan tersebut misalnya ikut dalam berkonsultasi gizi, mengingatkan pasien DM tentang jadwal makan, jenis makanan serta jumlah makanan yang harus dikonsumsi baik dalam bentuk makanan utama maupun makanan selingan.

\section{RUJUKAN}

1. Waspadji S, Suyono S, Sukardji K, Hartati. Pengkajian status gizi studi epidemiologi. Jakarta: Pusat Diabetes Mellitus dan Lipid RSCM; 2003.

2. Tandra H. Panduan lengkap mengenal dan mengatasi DM dengan cepat dan mudah. Jakarta: Gramedia Pustaka Umum; 2008.

3. Harjodisastro D, Syam AF, Sukrisman L. ed. Dukungan nutrisi pada kasus penyakit dalam. Jakarta: Departemen IImu Penyakit Dalam FKUI; 2006.

4. Asdie AH. Patogenesis dan terapi diabetes mellitus tipe 2. Yogyakarta: Medika FK UGM; 2000.
5. Basuki E. Teknik penyuluhan diabetes melitus dalam: penatalaksanaan diabetes melitus terpadu. Jakarta: FKUI; 2007. 131-46.

6. Tresna N, Suryani I, Setyowati. Karakteristik dan kebiasaan makan pasien diabetes melitus rawat jalan di RSUD Sleman. Nutrisia 2007; 8 (2): 88-94.

7. Perkumpulan Endokrinologi Indonesia (PERKENI). Konsensus pengelolaan diabetes melitus tipe 2 di Indonesia. Jakarta; 2006.

8. Gross LS, Lili, Ford ES, Liu S. Increase consumption of refine carbohydrate and epidemic of tipe 2 diabetes melitus in United State: an ecology assesment. Am J Clin Nutr 2004; 79: 774-9.

9. Sukmaniah S. Nutrisi pada DM. Jakarta: Perhimpunan Dokter Gizi Medik Indonesia; 2000.

10. Riastuti N. Pengaruh kunjungan rumah terhadap kepatuhan diet dan kadar gula darah pasien diabetes mellitus tidak tergantung insulin rawat jalan di RS Dr. Sardjito. Yogyakarta: Fakultas Kedokteran Universitas Gadjah Mada; 2005.

11. Juleka, Asdie AH, Susetyowati. Hubungan pola makan dengan pengendalian kadar glukosa darah pengidap diabetes mellitus tipe 2 rawat jalan di RSU Gunung Jati Cirebon. Jurnal Gizi Klinik Indonesia 2005; 2 (1).

12. Reppie MR, Asdie AH, Astuti H. Pengaruh konseling gizi dengan buku saku diet pada pasien hiperurisemia rawat jalan di RSUD Noongan Provinsi Sulawesi Utara. Jurnal Gizi Klinik Indonesia 2007; 4(1): 35-42.

13. Dahlan SM. Statistik untuk kedokteran dan kesehatan. Jakarta: Salemba Medika; 2008.

14. Asmuni S. Depresi pada pasien diabetes mellitus di poliklinik penyakit dalam RSUP Dr. Sardjito. Yogyakarta: Fakultas Kedokteran Universitas Gadjah Mada; 2003.

15. Rifki N. Penatalaksanaan diabetes melitus dengan pendekatan keluarga dalam: penatalaksanaan diabetes mellitus terpadu. Jakarta: FKUI; 2007. 199-203.

16. Polonsky. Assessing psychosocial distress in diabetes melitus. Diabetes Care 2005; 28: 626-31.

17. Azwar A. Sikap manusia teori dan pengukurannya. Yogyakarta: Pustaka Pelajar; 2007.

18. Anoraga P. Psikologi kerja. Jakarta: PT Rineka Cipta; 2006. 11-43.

19. Sukardji K. Penatalaksanaan gizi pada diabetes melitus dalam: penatalaksanaan diabetes melituss terpadu. Jakarta: FKUI; 2007. 43-52.

20. Friedman MM. Family nursing: research, theory, \& practice, 4 Ed. Stanford: Appleton \& Lange; 1998.

21. Almatsier S. Prinsip dasar ilmu gizi. Jakarta: PT Gramedia Pustaka Utama; 2002. 279-95. 